\title{
Marshall Darrow Shulman, 1916-2007
}

The essential measure of a man, like the objects in Plato's cave, is best captured indirectly, by the shadow that he casts. The penumbra of Marshall Shulman's shadow was large indeed, extending to family, friends, colleagues, protégés, institutions, and nations. Devoted husband and father, Marshall made countless and untold sacrifices to raise his two children, Lisa and Michael, under trying circumstances after the death of his first wife, Elizabeth, in 1956. Innumerable friends, colleagues, and foreign guests benefited from the inspirational hospitality that Marshall and his second wife, Colette-herself a driving force in Russian-American social and educational affairs-bestowed upon them in Sherman, Connecticut, on Riverside Drive, and in Washington, D.C. As a friend, Marshall never hesitated to drop whatever he was doing to help a soul in need, as he did more than once for those unjustly accused during the McCarthy era (and at a time when he was a public servant working for Dean Acheson at the U.S. Department of State). One such soul, William Draper Carter, Marshall's boss in wartime Delhi, went on to head the educational division at UNESCO in Paris, where he established the modern system of international educational exchanges.

As scholar, colleague, and mentor, Marshall exemplified the academic calling, demanding rigorous scholarship of himself and his students while always encouraging the pursuit of original ideas, wherever they might lead. He was ferociously devoted to the life of the mind. His early works, including Stalin's Foreign Policy Reappraised (1963) and Beyond the Cold War (1966), stand even today as models of disciplined scholarship and penetrating analysis of Soviet diplomacy and the international political system, respectively.

During World War II, Marshall served his country as a glider pilot and in the Psychological Warfare Bureau of the U.S. Army, working in southeast Asia with Nisei translators in the frustrating enterprise of attempting to induce Japanese soldiers to surrender. That experience formed an element of Marshall's commitment to fostering area studies: it is often overlooked that the origins of "Cold War" area studies lay in the American academy's experience of World War II, both in terms of a vivid and mortal engagement in lands across the oceans as well as the voluntary collaboration of scholars from across disciplines to study a given country intensively and win the war (think of Herbert Marcuse and Vera Dunham practically side by side in the Office of Strategic Services, the wartime predecessor of the Central Intelligence Agency).

Discharged from the army with the Bronze Star, Marshall entered and graduated with the first class of the Russian Institute at Columbia University (1946), commuting by a now long-defunct ferryboat from the Jersey side of the Hudson River, just south of the George Washington Bridge. After an initial stint in Washington as special assistant and speechwriter for Acheson at the U.S. Department of State during the formative period of the Cold War, Marshall was recruited to become associate director at Harvard's Russian Research Center; he later (1961-67) assumed a professorial appointment at Tufts University's Fletcher School of Law and Diplomacy.

Marshall undoubtedly made his most significant institutional impact at Columbia's Russian Institute, which he joined as director in the fateful 1967-68 academic year. (Columbia failed to persuade Marshall to give up riding his BMW motorcycle as a condition of the appointment.) As director, Marshall was among the first to identify and analyze the shift in Soviet leadership calculations that made the détente of the early 1970 s possible. Relatedly, he was a central participant in the unofficial Soviet-American dialogue network known as the Dartmouth Conference; in this and like fora, Marshall worked heroically to establish and maintain a minimum of mutual comprehension among political elites in both countries throughout the vicissitudes of Cold War and détente; in this connection, he traveled to the Soviet Union and Russia more than forty times. Marshall also moved forcefully and effectively for the integration of nuclear arms control studies into the political science and Soviet area studies curricula; oversaw the bringing of the Khrushchev tapes to Columbia as well as the training of both Hedrick Smith and Robert Kaiser for their famous postings in the 1970s as Moscow correspondents for the New York Times and the Wash- 
ington Post, respectively; managed a successful million dollar fundraising campaign jointly with Harvard's Russian Research Center in the 1970s; secured multiple, multi-million dollar grants from the leading foundations to train a new generation of Soviet area specialists in the 1980s; and in 1982 convinced Averell and Pamela Harriman to commit an endowment of $\$ 11.5$ million (now grown to a multiple of that sum) to remake the Russian Institute, first as the W. Averell Harriman Institute for Advanced Study of the Soviet Union and, after 1992, as the multiregional Harriman Institute.

I came to know Marshall Shulman later than most, having studied at the Russian Institute at a time (1977-1980) when Marshall served in Washington as the chief Soviet advisor, with the rank of ambassador, to Secretary of State Cyrus Vance. Still, the mark of the man was indelibly imprinted on the institute during the years of his absence: intellectual rigor and interdisciplinary sensibility; burning concern for the issues of the day without bending to the politics of the day; rigorous, indeed, vigorous debate without ad hominem rancor; the obligations of legacy, to those on whose shoulders we stood as well as to those to whom we committed our own modest knowledge and mentorship; the commitment to integrating the best that the academy had to offer with public service, while respecting the specific vocation of each; and finally, the conviction, pace Winston Churchill, that "jawjaw" is almost always preferable to "war-war" and that the heavy burden of proof must always lie with those advocating the latter.

What I missed as a student in his absence I absorbed later when I helped administer the Harriman Institute and got to know Marshall in the flesh: his deep humanity, his puckish sense of humor, his happy willingness to write a letter or pick up the phone on behalf of a student or colleague at the drop of a hat, his utter integrity, his abiding concern with the fate of the world and of his country within it and of course his wonderful life-partnership with Colette.

In his last conversation with me, Marshall observed ruefully that so much of the international presumption in favor of the United States had been depleted in recent years and that it would be a long time before that positive opinion could be restored. What worthier charge for those of us who live in Marshall Shulman's shadow than to take up his call and labor in this work of restoration?

Allen C. LyNCH

University of Virginia

August 2007 